
MODY

\author{
Петрова Т.Г. ${ }^{1}$, Морева Н.А. ${ }^{1}$, Рымар С.Д. ${ }^{1}$, Овсянникова А.К. ${ }^{2}$, Рымар О.Д. ${ }^{2}$ \\ ${ }^{1}$ ФББОУ ВО «Новосибирский государственный медицинский университет» Минздрава России \\ ${ }^{2}$ НИИ терапии и профилактической медицины - филиал ФГБНУ «Федеральный исследовательский центр \\ Институт ц̧итологии и генетики СО РАН» (Новосибирск)
}

\title{
The condition of the oral cavity in patients with MODY type diabetes mellitus
}

\author{
Petrova T.G. ${ }^{1}$, Moreva N.A. ${ }^{1}$, Rymar S.D. ${ }^{1}$, Ovsyannikova A.K. ${ }^{2}$, Rymar O.D. ${ }^{2}$ \\ ${ }^{1}$ Novosibirsk State Medical University \\ ${ }^{2}$ Research Institute of Internal and Preventive Medicine (Novosibirsk)
}

\section{АННОТАЦИЯ}

В исследовании, посвященном оценке стоматологического статуса у пациентов с редкой формой диабета MODY, приняли участие 9 чел. (3 женщины и 6 мужчин). Диагноз MODY-диабета им был поставлен на основании результатов молекулярно-генетического исследования. У обследованных с разными подтипами (2, 6 и 12) MODYдиабета выявлена высокая интенсивность кариеса, воспалительных заболеваний пародонта и зубочелюстных аномалий, что существенно не влияло на качество жизни обследованных. В полости рта у больных MODY-диабетом подтипа 2 отсутствовали выраженные специфические проявления нарушений углеводного обмена, что, вероятно, может быть связано с хорошей компенсацией диабета. Также представлено клиническое описание MODY-диабета подтипа 2 у представителей двух поколений - отца и сына.

Ключевые слова: MODY-диабет, стоматологический статус, гликированный гемоглобин, кариес, индекс гингивита, индекс пародонтита.

\section{ABSTRACT}

In a study on the assessment of dental status in patients with a rare form of diabetes - MODY, 9 people were involved ( 3 women and 6 men). The diagnosis of MODY was based on the results of molecular genetic research. In patients with different subtypes (2, 6 and 12) of MODY a high intensity of caries, inflammatory periodontal diseases and dental anomalies was detected, which did not significantly affect the quality of life of the patients. In the oral cavity of patients with MODY subtype 2 there were no pronounced specific manifestations of disorders of carbohydrate metabolism, which probably can be associated with good diabetes compensation. Clinical descriptions of MODY subtype 2 in representatives of two generations - father and son - is also presented.

Keywords: MODY, dental status, glycated hemoglobin, caries, gingivitis index, periodontitis index.

\section{В ВЕДЕНИЕ}

Сахарный диабет 2-го типа (СД2) представляет собой мировую проблему в связи с большой распространенностью, достигшей в настоящее

\section{INTRODUCTION}

Type 2 diabetes mellitus (T2D) is a global problem due to the high prevalence that has now reached epidemic proportions in many develop-
Поступила 19.10.2018

Принята 15.01.2019

*Автор, ответственный за переписку

Рымар Оксана Дмитриевна: ФГБОУ ВО «Новосибирский государственный медицинский университет» Минздрава России. 630091, г. Новосибирск, Красный просп., 52

E-mail: orymar23@gmail.com
Received 19.10.2018

Accepted 15.01.2019

*Corresponding author

Rymar Oksana Dmitriyevna: Novosibirsk State Medical University, 52, Krasny Prospect, Novosibirsk, 630091, Russia.

E-mail: orymar23@gmail.com 
время масштабов эпидемии во многих развивающихся и в большинстве развитых стран. Распространенность СД2 в популяции быстро растет. В мире число больных данной патологией составило 425 млн чел. По данным Международной федерации диабета Российская Федерация входит в первую десятку стран с наибольшей численностью людей с диагнозом СД2 (8.5 млн) [1]. Растет количество молодых пациентов с диагностированным сахарным диабетом $[2,3]$. На борьбу с болезнью из бюджета здравоохранения тратится около 30 \% финансовых средств, при этом почти 90 \% из них расходуется на лечение осложнений, а не самой болезни.

Хроническая гипергликемия при СД2 сопровождается повреждением, дисфункцией и недостаточностью различных органов и систем, в том числе органов и тканей полости рта. СД2 признан фактором риска развития более тяжелых форм пародонтита. Воспалительные заболевания пародонта, согласно данным литературы, являются шестым осложнением СД, наряду с нейропатией, нефропатией, ретинопатией и микро- и макрососудистыми заболеваниями [4-6].

Диабет представляет собой гетерогенную группу метаболических заболеваний, характеризующихся этиологическими, патогенетическими и клиническими особенностями. Наряду с сахарным диабетом 1-го и 2-го типа типа существуют более редкие формы, вызванные генетическими мутациями. К таким формам относится «сахарный диабет взрослого типа у молодых» (MODY-диабет), который отличается клиническим течением, подходами к терапии и прогнозом. MODY-диабет - генетически обусловленная гетерогенная форма сахарного диабета с началом заболевания в молодом возрасте, аутосомно-доминантным типом наследования и наличием первичного дефекта в функции $\beta$-клеток поджелудочной железы $[7,8]$. К настоящему времени известно 14 форм MODY-диабета, самыми распространёнными являются подтипы 2, 3 и 5, на которые приходится 90 \% выявленных случаев. В г. Новосибирске MODY-диабет диагностирован у 22 пациентов старше 16 лет [9]. И если состояние полости рта у больных диабетом 1-го и 2-го типа описано в литературе достаточно подробно, то стоматологический статус у больных MODY-диабетом практически не изучен.

\section{ЦЕЛЬ ИССЛЕДОВАНИЯ}

Изучение стоматологического статуса у больных MODY-диабетом. ing and most developed countries. The prevalence of $\mathrm{T} 2 \mathrm{D}$ in the population is growing rapidly. In the world the number of patients with this pathology is 425 million people. According to the International Diabetes Federation, the Russian Federation is among the top ten countries with the largest number of people diagnosed with T2D (8.5 million) [1]. The number of young patients with diagnosed diabetes mellitus is growing [2, 3]. About 30\% of financial resources from the health budget are spent on fighting the disease, while almost 90\% of them are spent on treating complications, and not the disease itself.

Chronic hyperglycemia in T2D is accompanied by damage, dysfunction and insufficiency of various organs and systems, including organs and tissues of the oral cavity. T2D is recognized as a risk factor for the development of more severe forms of periodontitis. According to the literature, inflammatory periodontal diseases are the sixth complication of diabetes, along with neuropathy, nephropathy, retinopathy, and micro- and macrovascular diseases [4-6].

Diabetes is a heterogeneous group of metabolic diseases characterized by etiological, pathogenetic and clinical features. Along with type 1 and type 2 diabetes, there are rarer forms caused by genetic mutations. These forms include "Maturity onset diabetes of the young" (MODY), which differs in clinical course, approaches to therapy and prognosis. MODY is a genetically determined heterogeneous form of diabetes mellitus with the onset of the disease at a young age, autosomal dominant type of inheritance and the presence of a primary defect in the function of pancreatic $\beta$-cells $[7,8]$. To date, 14 forms of MODY are known, the most common are subtypes 2, 3 and 5, which account for $90 \%$ of the detected cases. In Novosibirsk MODY was diagnosed in 22 patients over 16 years [9]. While the state of the oral cavity in patients with type 1 and type 2 diabetes is described in the literature in sufficient detail, the dental status in patients with MODY is practically not studied.

\section{AIM OF THE RESEARCH}

The study of dental status in patients with MODY.

\section{MATERIALS AND METHODS}

Dental examination of 9 people (3 women and 6 men) with MODY verified on the basis of molecular genetic research was carried out. All examined 


\section{МАТЕРИАЛЫ И МЕТОДЫ}

Было проведено стоматологическое обследование 9 чел. (3 женщины и 6 мужчин) с MODY-диабетом, верифицированным на основе молекулярно-генетического исследования. Все обследованные являлись пациентами НИИ терапии и профилактической медицины (Новосибирск) (НИИТПМ). Группа пациентов с MODY-диабетом была гетерогенна: 7 чел. с MODY-диабетом подтипа 2 (MODY-2), 1 чел. с MODY-диабетом подтипа 6 (MODY-6) и 1 пациент с MODY-диабетом подтипа 12 (MODY-12). Возраст обследованных варьировал от 16 до 43 лет и в среднем составил $29.78 \pm 13.24$ года. На момент обследования 2 пациента получали терапию инсулином, 1 - пероральными сахароснижающими препаратами, 5 чел. нормализовывали показатели глюкозы крови соблюдением диеты. Средний уровень гликированного гемоглобина (HbA1c) составил $6.4 \pm 0.8 \%$, что свидетельствует о хорошей компенсации углеводного обмена у обследованных пациентов.

При изучении стоматологического статуса оценивалось состояние слизистой оболочки рта, учитывались вид прикуса, положение зубов в зубной дуге, состояние височно-нижнечелюстного сустава, наличие некариозных поражений твердых тканей зубов. Оценку гигиенического состояния полости рта проводили с помощью упрощенного гигиенического индекса Green - Vermillion (1964) и индекса зубного налета PI (Silness, Loe, 1964), состояния твердых тканей зубов - по индексу КПУ (индекс интенсивности кариеса зубов, который определяется количеством зубов с кариесом, пломбами и удаленных), КПп (количество поверхностей зубов с кариесом и пломбами). Для определения степени воспаления десны использовали индекс PМА в модификации Parma (1964). Степень кровоточивости десен оценивали по индексу PBI (Muhlemann - Saxer, 1975). Для выявления распространенности и интенсивности поражения пародонта применялся индекс гингивита GI (Loe, Silness, 1963), пародонтальный индекс PDI (Marthaler et al., 1971), при необходимости проводили рентгенографическое исследование. Для оценки качества жизни (КЖ) использовали валидированную русскоязычную версию опросника «Профиль влияния стоматологического здоровья» OHIP-49-RU [10]. У всех пациентов было получено информированное согласие на участие в исследовании (у лиц моложе 18 лет информированное согласие подписывал один из родителей). patients were patients of the Research Institute of Therapy and Preventive Medicine (Novosibirsk). The group of patients with MODY was heterogeneous: 7 people with MODY subtype 2 (MODY-2), 1 person with MODY subtype 6 (MODY-6) and 1 patient with MODY subtype 12 (MODY-12). The age of the examined varied from 16 to 43 years and averaged $29.78 \pm 13.24$ years. At the time of examination 2 patients received insulin therapy, $1-$ oral hypoglycemic drugs, 5 people normalized blood glucose levels by diet. The average level of glycated hemoglobin $(\mathrm{HbA} 1 \mathrm{c})$ was $6.4 \pm 0.8 \%$, which indicates a good compensation of carbohydrate metabolism in the examined patients.

In the study of dental status the state of the oral mucosa was assessed, the type of bite, the position of the teeth in the dental arch, the state of the temporomandibular joint, the presence of noncarious lesions of the hard tissues of the teeth were taken into account. The assessment of oral hygiene was carried out using the simplified hygienic index Green - Vermillion (1964) and the plaque index PI (Silness, Loe, 1964), the state of hard tissues of teeth - according to the DMF index (index of intensity of dental caries, which is determined by the number of teeth with caries, fillings and removed), DMFS (the number of surfaces of teeth with caries and fillings). To determine the degree of inflammation of the gums, the PMA index in the modification of Parma (1964) was used. The degree of bleeding of the gums was estimated by the PBI index (Muhlemann - Saxer, 1975). The gingival index GI (Loe, Silness, 1963) and the periodontal index PDI (Marthaler et al., 1971) were used to identify the prevalence and intensity of periodontal lesions, if necessary, x-ray examination was performed. To assess the quality of life (QL) we used a validated Russian version of the questionnaire "Oral Health Impact Profile” OHIP-49-RU [10]. Informed consent to participate in the study was obtained from all patients (in those younger than 18 years old, informed consent was signed by one of the parents).

\section{RESULTS AND DISCUSSION}

In the study of the dental status of patients with MODY it was established that all the examined patients complained of a dental nature. Most often patients complained of increased sensitivity of teeth to various types of irritants (66.7\%) and dryness in the oral cavity (44.4\%), less often - bleeding gums (33.3\%), bad breath, tooth decay, discomfort in the 


\section{РЕЗУЛЬТАТЫ И ОБСУЯКДЕНИЕ}

При изучении стоматологического статуса больных MODY-диабетом установлено, что все обследованные предъявляли жалобы стоматологического характера. Чаще всего пациенты жаловались на повышенную чувствительность зубов к различным видам раздражителей (66.7 \%) и сухость в полости рта (44.4\%), реже - на кровоточивость десен (33.3 \%), неприятный запах изо рта, разрушенность зубов, дискомфорт в полости рта. Один пациент жаловался на ограничения открывания рта.

При внешнем осмотре у 100 \% больных наблюдалась сухость красной каймы губ. У одного обследованного с MODY-2 диагностирован метеорологический хейлит. У этого же пациента выявлена лейкоплакия Таппейнера (пациент курит) и травматическая эрозия на твердом нёбе и слизистой щеки по линии смыкания зубов.

У всех обследованных диагностирован кариес. Интенсивность кариеса по индексу КПУ у больных MODY-диабетом была высокой и составила $11.0 \pm 1.5$. Количество запломбированных зубов (7.67 \pm 1.24$)$ преобладало над зубами, пораженными кариесом $(2.44 \pm 1.23)$. Рецидив кариеса под ранее поставленными пломбами в среднем по группе был равен $0.67 \pm$ 0.33. Удаленные зубы отмечены у 4 пациентов и в среднем по группе составили $0.78 \pm 0.29$. Интенсивность кариеса по индексу КПп была 19.0 土 2.49. Чаще кариозный процесс регистрировался на окклюзионных (46.5 \%) и контактных поверхностях (43.9 \%). Доля лиц, нуждающихся в лечении кариеса и его осложнений, составила 44.4 \%. Интенсивность кариеса зависела от возраста обследованных. У подростков индекс КПУ составил $8.33 \pm 1.2$, у пациентов старше 20 лет $-12.33 \pm 2.01$.

При изучении состояния пародонта только у одного обследованного с MODY-6 зарегистрировано отсутствие воспалительных явлений в пародонте. У 88.9 \% больных MODY-диабетом выявлен воспалительный процесс в тканях пародонта, сопровождающийся гиперемией, отеком, кровоточивостью. Тяжесть воспалительных заболеваний пародонта увеличивалась с возрастом. Так, у подростков с MODY-2 (3 чел.) и у больного MODY-12 воспаление в пародонте протекало без нарушения целостности зубодесневого соединения, что позволило диагностировать гингивит. У 4 больных MODY-2 среднего возраста выявлен хронический генерализованный пародонтит легкой и средней степеней тяжести. Кровоточивость десен, как один из наиболее информативных показателей наличия воспале- oral cavity. One patient complained of limitation of mouth opening.

On external examination a dry red border of the lips was observed in $100 \%$ of patients. One patient with MODY-2 was diagnosed with meteorological cheilitis. Tappeiner's leukoplakia (the patient smokes) and traumatic erosion on the hard palate and cheek mucosa along the line of teeth closing were detected in the same patient.

All patients were diagnosed with caries. The intensity of caries according to the DMF index in patients with MODY was high and amounted to $11.0 \pm 1.5$. The number of filled teeth $(7.67 \pm 1.24)$ prevailed over the teeth damaged by caries $(2.44 \pm 1.23)$. The recurrence of caries under the previously placed fillings was $0.67 \pm 0.33$ on average in the group. Removed teeth were noted in $4 \mathrm{pa}-$ tients and the average for the group was $0.78 \pm 0.29$. The intensity of caries by DMFS index was 19.0 \pm 2.49 . Most of the carious process was recorded on the occlusal (46.5\%) and contact surfaces $(43.9 \%)$. The proportion of people in need of treatment of caries and its complications was 44.4\%. The intensity of caries depended on the age of the examined. Adolescents DMF index amounted to $8.33 \pm 1.2$, in patients older than 20 years $12.33 \pm 2.01$.

In the study of the periodontal state only one examined with MODY-6 registered the absence of inflammatory phenomena in the periodontium. In 88.9\% of patients with MODY an inflammatory process was found in periodontal tissues, accompanied by hyperemia, edema, and bleeding. The severity of inflammatory periodontal disease increased with age. Thus, in adolescents with MODY-2 (3 people) and in the patient with MODY-12 inflammation in the periodontal disease proceeded without disturbance of the integrity of the periodontal junction, which made it possible to diagnose gingivitis. Chronic generalized periodontitis of mild and moderate severity was revealed in 4 middle age patients with MODY-2. Bleeding gums, as one of the most informative indicators of the presence of inflammation in periodontal tissues, was observed in 8 of 9 patients with MODY. The index of bleeding in patients with MODY and inflammatory periodontal disease was $1.47 \pm 0.38$ points. The prevalence and intensity of inflammatory periodontal diseases was estimated using the PMA index, which was $37.83 \pm 7.93 \%$. Gingival index GI, reflecting the intensity of inflammation, was equal to $1.44 \pm 0.22$ points. The periodontitis index PDI allowed to estimate not 
ния в тканях пародонта, отмечалась у 8 из 9 обследованных с MODY-диабетом. Индекс кровоточивости у больных MODY-диабетом и воспалительными заболеваниями пародонта составил $1.47 \pm 0.38$ балла. Распространенность и интенсивность воспалительных заболеваний пародонта оценивалась с помощью индекса PМА, который составил $37.83 \pm 7.93 \%$. Индекс гингивита GI, отражающий интенсивность воспаления, был равен $1.44 \pm 0.22$ балла. Индекс пародонтита PDI позволил оценить не только выраженность гингивита, но и утрату прикрепления и составил $2.58 \pm 1.02$.

Отложения на зубах преимущественно в виде мягкого зубного налета были обнаружены у всех обследованных при индексе зубного налета PI, равном $1.57 \pm 0.24$. Твердые зубные отложения выявлены у 44.4 \% больных. Суммарная оценка наличия твердых и мягких зубных отложений проводилась по индексу Green - Vermillion и составляла $1.74 \pm 0.29$, что соответствовало неудовлетворительной гигиене полости рта.

Сошлифовывание зубов проявлялось клиновидными дефектами и обнаружено у 2 обследованных (22.2 \%). Наличие клиновидных дефектов сопровождалось гиперестезией и рецессией десны.

Аномалии зубочелюстной системы встречались у всех обследованных с MODY-2. В боковых участках зубных рядов отмечалась медиальная и дистальная окклюзия, во фронтальном отделе глубокая и прямая резцовая окклюзия. У больных с MODY-6 и MODY-12 аномалий прикуса не установлено.

Аномалии положения зубов верхней и нижней челюстей обнаружены у 7 обследованных (77.8 \%) и были весьма разнообразны. В большинстве случаев аномалии зубов сочетались между собой и с другими аномалиями зубочелюстной системы. Наиболее часто встречались скученность и ротация зубов. У одного больного отмечены тремы и диастемы верхней и нижней челюстей, а также ретрузия нижних резцов и адентия двух нижних резцов.

Патология височно-нижнечелюстного сустава (ВНЧС) зафиксирована у 66.7 \% пациентов, что проявлялось щелчками в суставе, не сопровождающимися нарушением функции, и болевым синдромом (2 чел.), девиацией нижней челюсти (2 чел.). Двое больных отмечали в анамнезе эпизоды вывиха нижней челюсти, ограничения открывания рта, дискомфорт в ВНЧС.

Как показали результаты исследования качества жизни, индекс по OHIP-49-RU у больных only the severity of gingivitis, but also the loss of attachment and amounted to $2.58 \pm 1.02$.

Dental deposits mainly in the form of soft dental plaque were found in all patients with plaque index PI equal to $1.57 \pm 0.24$. Hard dental deposits were found in $44.4 \%$ of patients. The total assessment of the presence of hard and soft dental deposits was carried out according to the Green - Vermillion index and amounted to $1.74 \pm 0.29$, which corresponded to poor oral hygiene.

Tooth grinding was manifested by wedgeshaped defects and was found in 2 patients (22.2\%). The presence of wedge-shaped defects were accompanied by hypersensitivity and gingival recession.

Anomalies of the dentoalveolar system were found in all patients with MODY-2. Medial and distal occlusion was noted in the lateral parts of the dentition, in the frontal part - deep and direct incisional occlusion. No malocclusion was found in patients with MODY-6 and MODY-12.

Anomalies in the position of the teeth of the upper and lower jaws were found in 7 examined (77.8\%) and were very diverse. In most cases, dental anomalies were combined with each other and with other anomalies of the dentition. The most common were crowding and rotation of teeth. One patient had trema and diastema of the upper and lower jaws, as well as retrusion of the lower incisors and adentia of the two lower incisors.

Pathology of the temporomandibular joint (TMJ) was recorded in $66.7 \%$ of patients, which was manifested by clicks in the joint, not accompanied by dysfunction, and pain syndrome (2 people), deviation of the lower jaw (2 people). Two patients noted a history of episodes of dislocation of the lower jaw, restriction of mouth opening, discomfort in the TMJ.

As shown by the results of the study of quality of life, the OHIP-49-RU index in patients with MODY was $22.83 \pm 6.05$. The data obtained did not differ significantly from the control norm of the OHIP-49-RU index calculated for somatically preserved residents of the Russian Federation with intact oral cavity $(27.44 \pm 2.86)$.

Thus, the presented results indicate that the participation of dentists in maintaining the health of the body as a whole, through the provision of complex oral therapy in patients with MODY is required. Prevention and treatment of dental diseases in patients with MODY plays an important role in improving the quality of life of patients with this disease. 
MODY-диабетом составил $22.83 \pm 6.05$. Полученные данные статистически значимо не отличались от контрольной нормы индекса OHIP-49-RU, рассчитанной для соматически сохранных жителей РФ с интактной полостью рта $(27.44 \pm 2.86)$.

Таким образом, представленные результаты свидетельствуют о том, что требуется участие врачей-стоматологов в поддерживании состояния здоровья организма в целом, посредством комплексной терапии полости рта у пациентов с MODY-диабетом. Профилактика и лечение стоматологических заболеваний у больных MODY-диабетом играет важную роль в улучшении качества жизни пациентов с данным заболеванием.

Клинический пример: пациент Д. (2002 года рождения (г. р.) и его отец С. (1978 г. р.) направлены эндокринологом на стоматологическое обследование. Оба пациента в течение десяти лет наблюдаются с редкой формой сахарного диабета - GCK-MODY (MODY-2).

В 2018 г. проведён осмотр пациента Д. и его отца эндокринологом в НИИТПМ. Возраст мальчика на момент осмотра 16 лет (2002 г. р.). Жалобы не предъявляет. Психическое, физическое развитие соответствует возрасту. Простудными заболеваниями болеет 2 раза в год. Объективный статус без особенностей, ИМТ соответствует возрастной норме. Уровень НbA1с в 2018 г. в пределах целевых значений $-6.1 \%$. Пациент принимает глибенкламид (манинил м) 1.75 мг 1/4 табл. утром.

Отец пробанда (возраст 40 лет) жалоб при осмотре не предъявлял. Уровень НbА1с в пределах целевых значений $-6.4 \%$, диету не соблюдает, сахароснижающие препараты не принимает. Для коррекции артериальной гипертензии (АГ) принимает эналаприл 10 мг в сутки.

Из анамнеза: мальчик родился от первой беременности (у матери самопроизвольные роды в 39-40 нед), вес при рождении 2650 г, рост 49 см. В 5 лет 8 мес (июль 2008 г.) появилась жажда, кожный зуд, уровень глюкозы натощак 6.7 ммоль/л (капиллярная кровь), поставлен диагноз «Нарушение толерантности к углеводам (НТГ)». В 2009 г. (в возрасте 7 лет) диагностирован СД (тип, требующий уточнения). Лабораторные показатели в 2008 г.: антитела GAD, к инсулину, к ICA отрицательны, уровень HbA1c $-5.9 \%$, ТТГ 1.5 мкМЕ/мл, антитела к ТПО менее 10. Уровень С-пептида в 2010 г. - 0.562 нг/мл (референсные значения 0.7-1.9 нг/мл). Пациент соблюдал диету с ограничением легкоусвояемых углеводов. При гипергликемии принимал препараты суль-
Clinical example: patient D. (born in 2002) and his father S. (born in 1978) were referred by an endocrinologist for dental examination. Both patients for ten years are observed with a rare form of diabetes mellitus - GCK-MODY (MODY-2).

In 2018 the examination of the patient D. and his father is an endocrinologist in of the Research Institute of Internal and Preventive Medicine was conducted. The age of the boy at the time of examination was 16 years (born in 2002). No complaints. Mental, physical development corresponds to age. Catarrhal diseases sick 2 times a year. Objective status without features, BMI corresponds to the age norm. The HbA1c level in 2018 within the target values is $6.1 \%$. The patient takes glibenclamide (maninil m) $1.75 \mathrm{mg} 1 / 4$ table in the morning.

The father of the proband (40 years old) did not make any complaints during the examination. HbA1c level within target values $-6.4 \%$, does not follow the diet, does not take glucose-lowering drugs. For the correction of arterial hypertension (AH) takes enalapril $10 \mathrm{mg}$ per day.

From the anamnesis: the boy was born from the first pregnancy (spontaneous labor in 39-40 weeks), birth weight is $2650 \mathrm{~g}$, height $-49 \mathrm{~cm}$. In 5 years 8 months (July 2008) appeared thirst, itching, fasting glucose $6.7 \mathrm{mmol} / \mathrm{l}$ (capillary blood), he was diagnosed with "Impaired carbohydrate tolerance". In 2009 (at the age of 7 years) diabetes was diagnosed (type requiring clarification). Laboratory values in 2008: GAD antibodies are negative to insulin and ICA, HbA1c level $-5.9 \%$, $\mathrm{TSH}-1.5 \mu \mathrm{IU} / \mathrm{ml}$, antibodies to TPO are less than 10. C-peptide level in $2010-0.562 \mathrm{ng} / \mathrm{ml}$ (reference values are $0.7-1.9 \mathrm{ng} / \mathrm{ml}$ ). The patient was on a diet with restriction of easily digestible carbohydrates. During hyperglycemia he took sulfonylureas in small doses or received insulin injections in small doses.

Patient D. showed no signs of diabetes, typical for the "classic" T1D (no ketoacidosis, weight loss, antibodies, the need for exogenous insulin) and T2D (no signs of insulin resistance, no overweight and obesity). Heredity: mother of a proband at the age of 30 years (2009) during the examination, after identifying diabetes in her son, was diagnosed with a disturbance of carbohydrate tolerance, father - at the age of 31 years (2009) during the examination revealed fasting hyperglycemia (6.0 $\mathrm{mmol} / \mathrm{l})$, grandmother of a proband on the father's side - glucose intolerance. Parents of the patient D. had no complaints. 
фонилмочевины в малых дозах либо получал инъекции инсулина в малых дозах.

У пациента Д. не отмечено признаков течения диабета, характерных для «классических» СД1 (отсутствуют кетоацидоз, снижение массы тела, антитела, потребность в экзогенном инсулине) и СД2 (отсутствуют признаки инсулинорезистентности, нет избыточной массы тела и ожирения). Наследственность: у матери пробанда в возрасте 30 лет (2009 г.) при обследовании после обнаружения СД у сына диагностировано нарушение толерантности к углеводам, у отца - в возрасте 31 года (2009 г.) при обследовании обнаружена гипергликемия натощак (6.0 ммоль/л), у бабушки пробанда по линии отца - НТГ. Родители пациента Д. жалоб не предъявляли.

Так как у ребёнка и его отца превалировала гипергликемия натощак (у отца была бессимптомная гипергликемия), наблюдалось стабильное течение СД, не было потребности в инсулинотерапии, был поставлен предварительный диагноз: GCK-MODY (MODY-2). Пациенту Д. в возрасте 8 лет проведено прямое автоматическое секвенирование 12 экзонов гена глюкокиназы. Обнаружена миссенс-мутация CTG > GTG в экзоне 4 в нуклиотидной позиции 146 (146C > G), приводящей к замене аминокислоты лейцина на валин (Leu146Val). Данная мутация характерна для GCK-MODY. Молекулярно-генетическое исследование было проведено родителям пробанда и его сестре (2014 г. р., возраст 5 мес на момент исследования). У матери и сестры пробанда изменений в гене глюкокиназы не выявлено. У отца обнаружена миссенс-мутация Leu146Val, идентичная мутации пробанда. Таким образом, в семье пациента Д. MODY-2 диагностирован в двух поколениях.

Стоматологический статус пациента Д.: при стоматологическом осмотре предъявляет жалобы на кровоточивость десен и повышенную чувствительность зубов. При внешнем осмотре отмечена сухость красной каймы губ. У пациента - глубокая резцовая окклюзия, ретрузия вторых верхних резцов, сужение нижнего зубного ряда, мелкое преддверие полости рта. Открывание рта свободное, безболезненное, при открывании рта определяется щелчок в ВНЧС слева. При осмотре полости рта зарегистрирована эрозия в стадии эпителизации по линии смыкания зубов слева, связанная с прикусыванием щеки. В анамнезе пациент отмечает неоднократное прикусывание щек. Интенсивность кариеса по индексу КПУ - 6, по индексу КПп 11. У пациента диагностирован гингивит хрони-
Since the child and his father had fasting hyperglycemia (the father had asymptomatic hyperglycemia), there was a stable course of diabetes, there was no need for insulin therapy and a preliminary diagnosis was made: GCK-MODY (MODY-2). Patient D. at the age of 8 years underwent direct automatic sequencing of 12 exons of the glucokinase gene. The missense mutation of CTG > GTG in exon 4 in the nucleotide position $146(146 \mathrm{C}>\mathrm{G})$, leading to the replacement of the amino acid leucine for valine (Leu146Val), was detected. This mutation is typical for GCK-MODE. Molecular genetic research was conducted in proband's parents and his sister (born in 2014, age 5 months at the time of the study). No changes in the glucokinase gene were detected in the mother and sister of the proband. The father discovered a missense mutation Leu$146 \mathrm{Val}$, identical to the proband mutation. Thus, in the family of the patient D. MODY-2 was diagnosed in two generations.

Dental status of the patient D.: during dental examination complains of bleeding gums and increased sensitivity of the teeth. An external examination marked dry red border of the lips. The patient has a deep incisional occlusion, retrusion of the second upper incisors, narrowing of the lower dentition, small vestibule of the oral cavity. Opening the mouth is free, painless, when opening the mouth is determined by a click in the TMJ on the left. During the examination of the oral cavity erosion was registered in the epithelialization stage along the closing line of the teeth on the left, associated with cheek biting. In the history of the patient notes repeated biting cheeks. The intensity of caries according to the DMF index -6 , DMFS index -11 . The patient was diagnosed with gingivitis chronic simple marginal generalized, accompanied by pronounced bleeding gums (PBI index - 3.54), high intensity and prevalence of gingival inflammation (PMA index - 70.24\%), as well as an abundance of soft dental plaque (PI index -2.67 ).

Patient C. at the dental examination complained about the destruction of the teeth. An external examination revealed dryness of the red border of the lips. When opening the mouth, there is a deviation of the lower jaw. The patient has a deep bite, crowding of teeth in the anterior part of the lower and upper jaws. On examination, the oral mucosa was diagnosed with Tappeiner's leukoplakia (the patient has a long smoking history, smokes more than one pack a day). The intensity of caries according to the DMF index -14 , DMFS index -26 . The patient was 
ческий простой маргинальный генерализованный, сопровождающийся выраженной кровоточивостью десен (индекс РВI - 3.54), высокой интенсивностью и распространенностью воспаления десны (индекс РМА - $70.24 \%$ ), а также обилием мягкого зубного налета (индекс РI - 2.67).

Пациент С. при стоматологическом осмотре предъявлял жалобы на разрушенность зубов. При внешнем осмотре обнаружена сухость красной каймы губ. При открывании рта наблюдается девиация нижней челюсти. У пациента глубокий прикус, скученность зубов во фронтальном отделе нижней и верхней челюстей. При осмотре слизистой оболочки рта диагностирована лейкоплакия Таппейнера (пациент имеет большой стаж курения, выкуривает больше пачки в день). Интенсивность кариеса по индексу КПУ 14, по индексу КПп - 26. У пациента выявлен пародонтит хронический генерализованный средней степени тяжести (индекс PBI -2.59 ; индекс PMA - 45.68 \%; индекс PI - 2.0; индекс пародонтита PDI - 4.83).

Таким образом, несмотря на то, что при GCK-MODY нарушена функция $\beta$-клеток и гепатоцитов, гипергликемия, ассоциированная с дефектами глюкокиназы, обычно умеренная. В приведённом клиническом случае в полости рта у больных MODY-2 отсутствовали выраженные специфические проявления нарушений углеводного обмена, что, вероятно, может быть связано с хорошей компенсацией СД на протяжении десяти лет.

\section{ЗАКЛЮЧЕНИЕ}

При изучении стоматологического статуса у больных MODY-диабетом выявлена высокая интенсивность кариеса зубов, распространенность воспалительных заболеваний пародонта и зубочелюстных аномалий, что существенно не влияло на качество жизни обследованных. В полости рта у больных MODY-диабетом отсутствовали выраженные специфические проявления нарушений углеводного обмена, что, вероятно, мо-

\section{СПИСОК ЛИТЕРАТУРЫ}

1. Cho N.H., Shaw J.E., Karuranda S. et al. IDF diabetes atlas: Global estimates of diabetes prevalence for 2017 and projections for 2045 // Diabetes Res. Clin. Pract. 2018. Vol. 138. P. 271-281. doi: 10.1016/j. diabres.2018.02.023.

2. Дедов И.И., Шестакова М.В., Галстян Г.Р. Распространенность сахарного диабета 2 типа у взрослого населения России (исследование NATION) // Сахарный диабет. 2016. Т. 19 (2). С. 104-112. diagnosed with chronic generalized periodontitis of moderate severity (PBI index -2.59 ; PMA index 45.68\%; PI index - 2.0; PDI index - 4.83).

Thus, despite the fact that the function of $\beta$-cells and hepatocytes is impaired in GCK-MODY, hyperglycemia associated with glucokinase defects is usually mild. In the above clinical case in the oral cavity in patients with MODY-2 there were no pronounced specific manifestations of carbohydrate metabolism disorders, which may be associated with good DM compensation for ten years.

\section{CONCLUSION}

The study of dental status in patients with MODY revealed high intensity of dental caries, the prevalence of inflammatory periodontal diseases and dentoalveolar anomalies, which did not significantly affect the quality of life of the examined. In the oral cavity in patients with MODY there were no pronounced specific manifestations of carbohydrate metabolism disorders, which may be associated with good diabetes compensation. Taking into account the fact that each subtype of diabetes has its own clinical features, in our opinion, it is interesting to conduct further comparative analysis of the oral cavity in patients with different subtypes of diabetes.

Conflict of interest. The authors declare no conflict of interest.

жет быть связано с хорошей компенсацией СД. Учитывая, что каждый подтип диабета имеет свои особенности клинического течения, интересным, на наш взгляд, представляется дальнейший сравнительный анализ состояния полости рта у больных разными подтипами диабета.

Конфликт интересов. Авторы заявляют об отсутствии конфликта интересов.

\section{REFERENCES}

1. Cho N.H., Shaw J.E., Karuranda S. et al. (2018). IDF diabetes atlas: Global estimates of diabetes prevalence for 2017 and projections for 2045. Diabetes Res. Clin. Pract., 138, 271-281. doi: 10.1016/j.diabres.2018.02.023.

2. Dedov I.I., Shestakova M.V., Galstyan G.R. (2016). The prevalence of type 2 diabetes mellitus in the adult population of Russia (NATION study). Diabetes Mellitus, 19, 2, 104-112. 
3. Мустафина С.В., Рымар О.Д., Малютина С.К. и др. Распространенность сахарного диабета у взрослого населения Новосибирска // Сахарный диабет. 2017. T. 20 (5). C. $329-334$.

4. Löe H. Periodontal disease: The sixth complication of diabetes mellitus // Diabetes Care. 1993. Vol. 16. P. $329-334$.

5. Sanz M., Ceriello A., Buysschaert M. et al. Scientific evidence on the links between periodontal diseases and diabetes: Consensus report and guidelines of the joint workshop on periodontal diseases and diabetes by the International Diabetes Federation and the European Federation of Periodontology // J. Clin. Periodontol. 2018. Vol. 45 (2). P. 12. doi: 10.1111/ jcpe.12808.

6. Петрова Т.Г., Бородина Н.Б., Рымар С.Д. и др. Взаимодействие стоматолога с эндокринологом - командный подход в лечении воспалительных заболеваний пародонта у пациентов с сахарным диабетом 2-го типа (обзор литературы) // Пародонтология. 2019. Т. 24 (2). С. 140-144.

7. Tattersall R.B., Fajans S.S., Arbor A. A difference between the inheritance of classical juvenile-onset and maturity-onset type diabetes of young people // Diabetes. 1975. Vol. 24 (1). P. 44-53.

8. Brunerová L., Urbanová J., Brož J. Current treatment options in Maturity-Onset Diabetes of the Young // Vnitr. Lek. 2018. Vol. 64 (4). P. 375-379.

9. Воевода М.И., Шахтшнейдер Е.А., Рымар О.Д. и др. Молекулярная генетика и клиника MODYдиабета / под общ. ред. М.И. Воеводы; ФГБНУ НИИТПМ. Новосибирск: Изд-во СО РАН, 2017. 164 с.

10. Гилева О.С., Халилаева Е.В., Либик Т.В. и др. Многоступенчатая валидизация международного опросника качества жизни «Профиль влияния стоматологического здоровья» ОНIP-49-RU // Урал. мед. журн. 2009. № 8. С. 104-109.

\section{СВЕДЕНИЯ ОБ АВТОРАХ}

Петрова Татьяна Геннадьевна - д-р мед. наук, профессор, заведующий кафедрой терапевтической стоматологии ФГБОУ ВО «Новосибирский государственный медицинский университет» Минздрава России.

Морева Нина Андреевна - канд. мед. наук, доцент кафедры терапевтической стоматологии ФГБОУ ВО «Новосибирский государственный медицинский университет» Минздрава России.

Рымар Софья Дмитриевна - студентка стоматологического факультета ФГБОУ ВО «Новосибирский государственный медицинский университет» Минздрава России.

Овсянникова Алла Константиновна - канд. мед. наук, научный сотрудник лаборатории клиникопопуляционных и профилактических исследований терапевтических и эндокринных заболеваний НИИ терапии и профилактической медицины - филиала ФГБНУ «Федеральный исследовательский центр Институт цитологии и генетики СО РАН» (Новосибирск).

Рымар Оксана Дмитриевна - д-р мед. наук, заведующий лабораторией клинико-популяционных и профилактических исследований терапевтических и эндокринных заболеваний НИИ тера-
3. Mustafina S.V., Rymar O.D., Malyutina S.K. et al. (2017). The prevalence of diabetes in the adult population of Novosibirsk. Diabetes Mellitus, 2O, 5, 329334 .

4. Löe H. (1993). Periodontal disease: The sixth complication of diabetes mellitus. Diabetes Care, 16, 329334.

5. Sanz M., Ceriello A., Buysschaert M. et al. (2018). Scientific evidence on the links between periodontal diseases and diabetes: Consensus report and guidelines of the joint workshop on periodontal diseases and diabetes by the International Diabetes Federation and the European Federation of Periodontology. J. Clin. Periodontol, 45, 2, 12. doi: 10.1111/ jcpe.12808.

6. Petrova T.G., Borodina N.B., Rymar S.D. et al. (2019). The interaction of the dentist with an endocrinologist - team approach in the treatment of inflammatory periodontal diseases in patients with type 2 diabetes (literature review). Periodontology, 24, 2, 140-144. In Russ.

7. Tattersall R.B., Fajans S.S., Arbor A. (1975). A difference between the inheritance of classical juvenileonset and maturity-onset type diabetes of young people. Diabetes, 24, 1, 44-53.

8. Brunerová L., Urbanová J., Brož J. (2018). Current treatment options in Maturity-Onset Diabetes of the Young. Vnitr. Lek., 64, 4, 375-379.

9. Voevoda M.I. (ed.), Shakhtshneider E.A., Rymar O.D. et al. (2017). Molecular Genetics and Clinical Picture of MODY. Novosibirsk, 164 p. In Russ.

10. Gileva O.S., Khalilaeva E.V., Libik T.V. et al. (2009). Multistep validation of the international questionnaire of quality of life "Oral health impact profile" (OHIP-49-RU). Ural Med. Journal, 8, 104-109.

\section{ABOUT THE AUTHORS}

Petrova Tatyana Gennadyevna - Dr. Sci. (Med.), Professor, Head of the Therapeutic Dentistry Department, Novosibirsk State Medical University.

Moreva Nina Andreyevna - Cand. Sci. (Med.), Associate Professor of the Therapeutic Dentistry Department, Novosibirsk State Medical University.

Rymar Sofya Dmitrievna - Student of the Dental Faculty, Novosibirsk State Medical University.

Ovsyannikova Alla Konstantinovna - Cand. Sci. (Med.), Researcher of the Laboratory of Clinical Population and Preventive Studies of Therapeutic and Endocrine Diseases, Research Institute of Internal and Preventive Medicine (Novosibirsk).

Rymar Oksana Dmitriyevna - Dr. Sci. (Med.), Head of the Laboratory of Clinical Population and Preventive Studies of Therapeutic and Endocrine Diseases, Research Institute of Internal and Preventive Medicine (Novosibirsk).

Citation example: Petrova T.G., Moreva N.A., Rymar S.D., Ovsyannikova A.K., Rymar O.D. (2019). The condition of the oral cavity in patients with MODY type diabetes mellitus. Journal of Siberian Medical Sciences, $3,74-83$. 
пии и профилактической медицины - филиала ФГБНУ «Федеральный исследовательский центр Институт цитологии и генетики СО РАН» (Новосибирск).

Образец ци ти ров ания : Петрова Т.Г., Морева Н.А., Рымар С.Д., Овсянникова А.К., Рымар О.Д. Состояние полости рта у пациентов с сахарным диабетом типа MODY // Journal of Siberian Medical Sciences. 2019. № 3. C. $74-83$. 